\title{
Nanosilver induces minimal lung toxicity or inflammation in a subacute murine inhalation model
}

\author{
Larissa V Stebounova', Andrea Adamcakova-Dodd², Jong Sung Kim³ ${ }^{3}$, Heaweon Park', Patrick T O'Shaughnessy ${ }^{2}$, \\ Vicki H Grassiann ${ }^{1,2,3}$, Peter S Thorne ${ }^{2,3^{*}}$
}

\begin{abstract}
Background: There is increasing interest in the environmental and health consequences of silver nanoparticles as the use of this material becomes widespread. Although human exposure to nanosilver is increasing, only a few studies address possible toxic effect of inhaled nanosilver. The objective of this study was to determine whether very small commercially available nanosilver induces pulmonary toxicity in mice following inhalation exposure.

Results: In this study, mice were exposed sub-acutely by inhalation to well-characterized nanosilver $\left(3.3 \mathrm{mg} / \mathrm{m}^{3}\right.$, 4 hours/day, 10 days, $5 \pm 2 \mathrm{~nm}$ primary size). Toxicity was assessed by enumeration of total and differential cells, determination of total protein, lactate dehydrogenase activity and inflammatory cytokines in bronchoalveolar lavage fluid. Lungs were evaluated for histopathologic changes and the presence of silver. In contrast to published in vitro studies, minimal inflammatory response or toxicity was found following exposure to nanosilver in our in vivo study. The median retained dose of nanosilver in the lungs measured by inductively coupled plasma - optical emission spectroscopy (ICP-OES) was $31 \mu \mathrm{g} / \mathrm{g}$ lung (dry weight) immediately after the final exposure, $10 \mu \mathrm{g} / \mathrm{g}$ following exposure and a 3-wk rest period and zero in sham-exposed controls. Dissolution studies showed that nanosilver did not dissolve in solutions mimicking the intracellular or extracellular milieu.
\end{abstract}

Conclusions: Mice exposed to nanosilver showed minimal pulmonary inflammation or cytotoxicity following subacute exposures. However, longer term exposures with higher lung burdens of nanosilver are needed to ensure that there are no chronic effects and to evaluate possible translocation to other organs.

\section{Background}

With increasing use of manufactured nanoparticles the potential for exposure among manufacturers and consumers is also increasing. Many of these manufactured nanomaterials are composed of metal and metal oxides and there have been reports of metal-containing nanoparticles in workplaces [1], from industrial sources detected in the atmosphere $[2,3]$ and in surface waters [4,5]. Silver nanoparticles, often referred to as nanosilver, may be problematic because of their use in a wide range of applications due to their antimicrobial activity [6-8]. Nanosilver is used for treatments of wounds, burns, water or air disinfection, or as coatings on various textiles [9]. There is concern that little is known

\footnotetext{
* Correspondence: peter-thorne@uiowa.edu

${ }^{2}$ Department of Occupational and Environmental Health, University of lowa, lowa City, IA 52242, USA

Full list of author information is available at the end of the article
}

about the environmental and health consequences of exposure to nanosilver.

Prior in vitro studies of nanosilver toxicity [10-15] reveal toxic effects of nanosilver through reduced cell viability, damage to the cell membrane and other biological effects on the organism. Nanosilver has been reported to be among the most toxic nanomaterials in some studies [10,16-18]. The cytotoxicity of nanosilver has been associated with generation of reactive oxygen species $[10,19]$ and several studies suggest that nanosilver is only toxic when oxidized to silver ions, $\mathrm{Ag}^{+}[12,14]$.

Most of the in vitro studies show dose dependence, where higher doses of Ag induce higher cellular toxicity. In contrast to in vivo investigations, in vitro concentrations of nanoparticles are often much higher and the particles are delivered to the cells via the culture medium. Such exposures do not replicate the conditions expected for in vivo exposure. Currently, there is no direct correlation of biological markers of toxicity between in vivo and

\section{Biomed Central}


in vitro studies due to the complexity of dose delivery, mono- vs. co-cultures, endpoint evaluations as well as other factors of cellular interaction with different biological media [20,21]. Even though air-liquid in vitro systems have been recently developed that may have more predictive value [22-25], in vivo studies are still considered to be more relevant for risk assessment.

Although inhalation is considered the most important route of exposure for nanoparticles [26,27], little is known about the environmental and health risks of aerosolized nanosilver [28]. There are a few reports in the literature on pulmonary studies of nanosilver toxicity in rats [7,29-32]. In these studies silver was detected in the lungs and, at much lower concentration, in the liver, brain, olfactory bulb and blood indicating organ translocation of nanosilver. No significant health implications were found for short exposure time periods although some pathologic responses were observed for higher Ag doses or longer exposures, such as chronic alveolar inflammation, small granulomatous lesions, and a decrease in the tidal and minute volume of the lungs. However, there are significant gaps in the toxicity studies of nanosilver and more thorough investigations with well characterized materials are warranted [6].

An integrated approach that includes both inhalation toxicology studies and full characterization of the nanomaterials is necessary for understanding inflammatory responses as they relate to the physicochemical principles of nanoparticle toxicity. In the current study, such an approach is used to assess the potential toxic effects associated with the inhalation of commercial nanosilver using a murine model for lung inflammation, histopathology, and dosimetry.

\section{Materials and methods Nanoparticles}

Nanosilver with a manufacturer's stated average particle size of $10 \mathrm{~nm}$ (minimum $5 \mathrm{~nm}$, maximum $15 \mathrm{~nm}, \mathrm{BET}=$ $\left.(10+1) \mathrm{m}^{2} / \mathrm{g}\right)$ were in powder form and used as received from the manufacturer (Stock \# 0478 YD, Nanostructured and Amorphous Materials, Inc, Houston, TX).

The nanosilver was characterized using transmission electron microscopy (TEM), X-ray diffraction (XRD), X-ray photoelectron spectroscopy (XPS), and BET techniques [33]. The bulk crystalline phases of Ag nanoparticles were determined using powder XRD measurements (Bruker D-5000 q - q diffractometer with Kevex-sensitive detector, Madison, WI). TEM (JEOL JEM-1230, Japan) was used to measure the primary particle size of 500 random nanoparticles and compare the average to manufacturer's specifications.

Surface properties, surface area, and composition of the Ag nanoparticles were examined. Surface area measurements of the powder sample were made on automated multipoint BET surface area apparatus (Quantachrome Nova 4200e, Boynton Beach, Florida) using nitrogen as the adsorbent. X-ray photoelectron spectroscopy (XPS) was used to probe the surface chemical composition characteristics of the metal nanoparticles (customdesigned Ultra-Axis XPS system from Kratos, Manchester, UK).

Dissolution studies were conducted in two different types of artificial fluids using inductively coupled plasma optical emission spectrometer (ICP-OES) (Varian Inc. 720-ES, Walnut Creek, CA). Ag nanoparticles were incubated in artificial interstitial fluid (Gamble's solution, $\mathrm{pH}=7.4$ ) and artificial lysosomal fluid (ALF, $\mathrm{pH}=$ 4.5) at a concentration of $2 \mathrm{mg} / \mathrm{ml}$ for 24 hours at $38^{\circ} \mathrm{C}$. The ALF solution simulates the composition and $\mathrm{pH}$ of alveolar and interstitial macrophages and the Gamble's solution simulates interstitial fluid in the lungs [34]. The compositions of the simulated biological fluids can be found in Ref. [35]. The final solutions were filtered by a syringe through $0.2 \mu \mathrm{m}$ filter and centrifuged for $30 \mathrm{~min}$ utes at 14,000 rpm in order to remove nanoparticles and aggregates that were not dissolved. The filtered and centrifuged solutions were analyzed by ICP-OES.

\section{Animals}

Male (6 weeks old) C57Bl/6 mice (The Jackson Laboratory, Bar Harbor, ME) were quarantined for 12 days after their arrival in our vivarium in polypropylene, fiber-covered cages in HEPA-filtered Thoren caging units (Hazelton, PA) in the Pulmonary Toxicology Facility at the University of Iowa prior to use. Mice were supplied with food (sterile Teklad 5\% stock diet, Harlan, Madison, WI) and water ad libitum and maintained on a 12-hr light-dark cycle. The average weight of the animals at the time of necropsy was $22.4 \mathrm{~g}$ at 0 wk post exposure and $26.8 \mathrm{~g}$ at 3 weeks post exposure. Shamexposed control mice had a mean weight of $26.9 \mathrm{~g}$ at the time of necropsy. Protocols were approved by the Institutional Animal Care and Use Committee at the University of Iowa and complied with the NIH Guide for the Care and Use of Laboratory Animals.

\section{Exposure Generation and Characterization}

A dynamic whole-body exposure chamber [36] was used to expose animals to nanosilver. Sham-exposed mice breathed filtered room air in an identical chamber setup. A suspension of nanosilver in ultra-pure water (Milli-Q ${ }^{\circledR}$ Academic A-10, Millipore Corp., Billerica, MA) was ultra-sonicated (model 550, Fisher Scientific, Pittsburgh, PA) for $20 \mathrm{~min}$. Aerosols of this suspension were generated using a 6-jet Collison nebulizer (BGI Inc., Waltham, MA) supplied with filtered, pressurized air (24 psi) and passed through a $60 \mathrm{~cm} \times 2 \mathrm{~cm}$ (I.D.), brass drying column heated to $110^{\circ} \mathrm{C}$ as well as a $20 \mathrm{mCi}{ }^{63} \mathrm{Ni}$ source to completely evaporate droplets and neutralize charges on the particles prior to 
introduction into the exposure chamber. Gravimetric concentrations of particles were measured in the chamber using 47-mm glass microfiber filters (Whatman, Middlesex, United Kingdom) in line with the 24 1/min exhaust airflow. With the additional heat and humidity supplied to the chamber, the temperature and relative humidity in the exposure chamber during the experiments was controlled between $20-22^{\circ} \mathrm{C}$ and $25-35 \%$, respectively. Electron microscopy grids were placed inside the exposure chamber for analysis of deposited nanoparticles. The grids were analyzed using scanning electron microscopy with an energy dispersive spectrometer (SEM-EDS) (Hitachi S-3400N, Japan) capable of providing elemental analysis of the particles. This confirmed the presence of nanosilver on the grid from the whole-body chamber during inhalation exposures. The size distribution of the aerosol in the whole-body exposure chamber was measured using a scanning mobility particle sizer (SMPS, TSI Inc., Shoreview, MN) for diameters in the range of 7.4 to $289 \mathrm{~nm}$. Geometric mean (GM) and geometric standard deviation (GSD) of aerosol sizes in individual exposures were calculated from SMPS measurements.

\section{Inhalation Exposure}

Mice were exposed sub-acutely to nanosilver for 4 hours/day, 5 days/week for 2 weeks and necropsied within one hour ( $0 \mathrm{wk}$ ) or 3 weeks post exposure (3 wks). The experimental design of this study is shown in Figure 1. The average concentration of nanosilver was $3.3 \pm 0.5 \mathrm{mg} / \mathrm{m}^{3}$ (range $\left.=2.4-4.0 \mathrm{mg} / \mathrm{m}^{3}\right)$. A minute volume of $25 \mathrm{ml}$ and particle deposition fraction $(\alpha)$ in the tracheo-bronchiolar and pulmonary region of $0.15[37,38]$ were assumed to estimate nanosilver dose.

\section{Bronchoalveolar Lavage}

Mice were euthanized by isoflurane inhalation and exsanguination through the heart. Lungs (from 5 animals per each experimental group) were lavaged 3 times with $1 \mathrm{ml}$ of $0.9 \%$ sterile sodium chloride solution (Baxter, Deerfield, IL) and the cell pellet was used for enumeration of total and differential cell counts as previously described [39]. Cells recovered from bronchoalveolar lavage (BAL) fluid were processed for TEM-EDS analyses $(n=1)$. Macrophages recovered from BAL fluid with and without Ag particles (100 cells per sample) were counted using dark field microscopy to assess the extent of the phagocytosis. The lavage supernatants $(\mathrm{n}=$ $5)$ were analyzed for total protein in 4 dilutions (1:5, $1: 10,1: 20$, and 1:40) using a Bradford protein assay (Bio-Rad Laboratories, Inc., Hercules, CA), lactate dehydrogenase (LDH) activity was measured in duplicates with a commercial assay (Roche Diagnostics, Penzberg, Germany) and cytokine levels measured by multiplexed

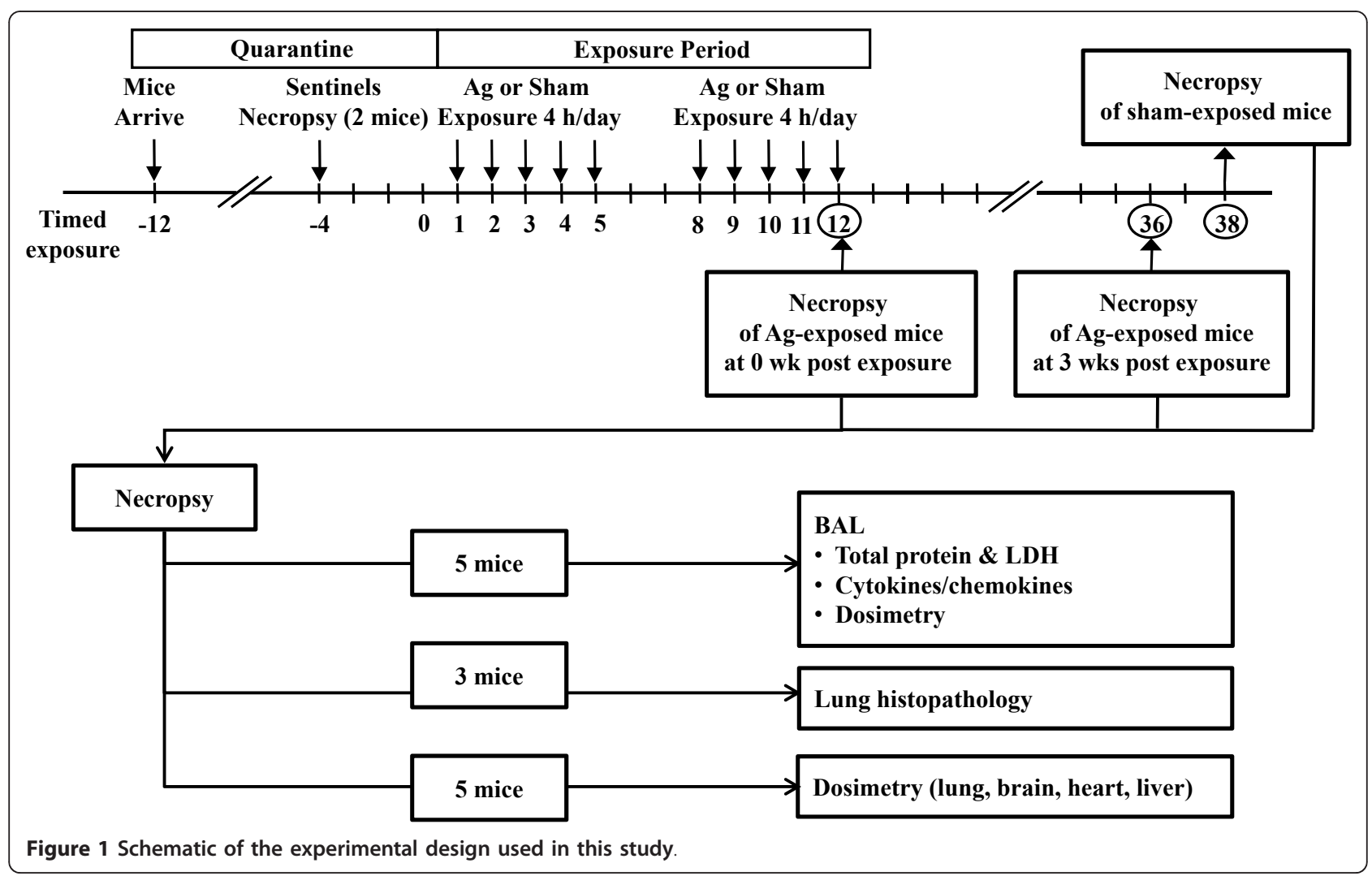


fluorescent bead-based immunoassays (Bio-Plex Pro Mouse Cytokine, Chemokine, and Growth Factor Multiplex Assays, Bio-Rad Laboratories, Inc., Hercules, CA). Measured cytokines included: interleukin (IL)-6, IL-12 (p40), tumor necrosis factor (TNF)- $\alpha$, granulocyte macrophage colony stimulating factor (GM-CSF), keratinocyte-derived cytokine (KC), monocyte chemotactic protein $(\mathrm{MCP})-1$, and macrophage inflammatory protein (MIP)-1 $\alpha$. The BAL fluid $(n=5)$ was then centrifuged again at 22,000 rpm for $30 \mathrm{~min}$ and $\mathrm{Ag}$ concentration in BAL supernatants was measured by ICP-MS.

\section{Histopathology}

Lungs from non-lavaged mice $(\mathrm{n}=3)$ were fixed in $10 \%$ formaldehyde-phosphate-buffered saline solution via the canulated trachea. The tissues were paraffin-embedded, sectioned at $5 \mu \mathrm{m}$, and stained with hematoxylin and eosin (H \& E) as previously described [25]. Tissue sections were evaluated by light microscopy to elucidate abnormalities of the parenchymal architecture (bronchioles, alveoli, pleura, and vasculature); abnormal inflammatory infiltrates; presence or absence of acute lung injury; and presence or absence of fibrosis.

\section{Nanosilver dosimetry}

Lung, brain, heart, and liver tissues from 5 mice in each experimental group were stored at $-80^{\circ} \mathrm{C}$ immediately after resection. Tissues were lyophilized for 16 hours at $1.3 \times 10^{-1} \mathrm{mBar}$ and $-50^{\circ} \mathrm{C}$ in a freeze dryer (Labconco Corp., Kansas City, MO) and then weighted. High purity concentrated nitric acid (Fisher Optima $\left.{ }^{(}\right)$grade) was used to digest the tissues at $95-98^{\circ} \mathrm{C}$. Metal analysis was performed using ICP-OES (Varian 720 ES, Varian Inc., Walnut Creek, CA) with a method detection limit for Ag of $1.8 \mu \mathrm{g} / \mathrm{g}$ lung dry weight (d.w.).

\section{EDS-spectra of Ag nanoparticles in alveolar macrophages}

The BAL cells were fixed with $2.5 \%$ glutaraldehyde in $0.1 \mathrm{M} \mathrm{Na}$ cacodylate buffer, post fixed with $1 \%$ osmium tetroxide, dehydrated through graded ethanols and embedded in epoxy resin. Thins sections were cut at 80-90 nm on a Leica EM UC6 ultramicrotome (Leica Microsystems GmbH, Wetzlar, Germany) and placed on 200 mesh formvar/carbon coated nickel grids. Elemental analysis of the cells recovered from BAL was performed with a Thermo Fisher Noran System 7 (Waltham, MA) energy dispersive spectroscopy system (EDS) attached to a JOEL JEM-2100F (Tokyo, Japan) field emission transmission electron microscope. The TEM was operated at an accelerating voltage of $200 \mathrm{kV}$ in scanning mode combined with a high angle annular field detector (HAADF). NSS 2.2 software package was used to acquire and process the data.

\section{Statistical Analyses}

Data from nanosilver-exposed and sham-exposed animals were compared using $t$ tests for equal or unequal variances (SAS Ver. 9.2, SAS, Inc., Cary, NC). A p-value less than 0.05 was considered significant. Data are expressed as mean \pm standard error (SE) unless otherwise noted.

\section{Results}

\section{Particle Characterization}

The results of particle characterization are summarized in Figure 2 and Table 1. The XRD patterns in Figure 2A compare the nanosilver results with metallic silver and silver oxide $\left(\mathrm{Ag}_{2} \mathrm{O}, \mathrm{AgO}\right)$ reference spectra and demonstrate that the nanoparticles are metallic silver with no detectable silver oxide. Surface composition was also examined using XPS (Figure 2B) to test for the presence of an oxide surface layer. Peaks in the Ag3d, Ag3p, O1s, and $\mathrm{C} 1 \mathrm{~s}$ regions of the photoelectron spectrum were identified. The Ag3d doublet at $368.2 \mathrm{eV}$ and $374.2 \mathrm{eV}$ is consistent with silver in the $\mathrm{Ag}^{0}$ oxidation state. The O1s region does not show any oxygen peaks below 530 $\mathrm{eV}$ attributable to $\mathrm{AgO}$ or $\mathrm{Ag}_{2} \mathrm{O}$, but there is a peak due to $\mathrm{CO}_{3}{ }^{2-}$ at $530.7 \mathrm{eV}$. There are also unique peaks at 287.3 and $288.7 \mathrm{eV}$ which we attribute to $\mathrm{C}=\mathrm{O}$ and $\mathrm{CO}_{3}{ }^{2-}$, respectively. In summary, the XPS data indicate the presence of adventitious carbon, some carbonoxygen functionality, likely due to the use of polyvinylpyrrolidone (PVP) during synthesis to control particle size, and $\mathrm{Ag}_{2} \mathrm{CO}_{3}$ on the surface of the nanosilver, but no evidence of a silver oxide coating. This coating accounts for up to $17 \%$ of the nanoparticle mass, as determined by ICP analysis and corresponds to a coating thickness of approximately $0.7 \mathrm{~nm}$. A presence of PVP on Ag nanoparticles surface diminishes the propensity of nanoparticles towards aggregation [40] and shows a minimal effect on the $\mathrm{Ag}$ nanoparticles toxicity against prokaryotic bacteria [12]. The specific surface area of nanosilver was determined to be $3 \pm 2 \mathrm{~m}^{2} / \mathrm{g}$ using multi-point BET analysis and is lower than the manufacturer's specified specific surface area of $10 \pm 1 \mathrm{~m}^{2} / \mathrm{g}$.

A primary particle size distribution was generated from the TEM images (Figure $2 \mathrm{C}$ ) by measuring the two-dimensional diameter of more than 500 nanoparticles (Figure 2D). The first mode of the bimodal particle size distribution with a peak maximum at $5 \mathrm{~nm}$ accounted for 85 to $90 \%$ of the total particle count. The second mode, with a peak at $22 \mathrm{~nm}$, was attributed to larger particles that account for less than $15 \%$ of the total particle count.

The dissolution of Ag nanoparticles into Ag ions in ALF and Gamble's solution was studied using ICP-OES [34]. The bioavailability and toxicity of metal nanoparticles are often linked to the ability of the nanoparticles to deliver soluble metal ions to the surrounding tissue. Figure 3 shows that nanosilver dissolved less than $0.1 \%$ in either simulated biological fluid in 24 hours. The concentrations of $\mathrm{Ag}$ ions were measured in triplicate in ALF and 

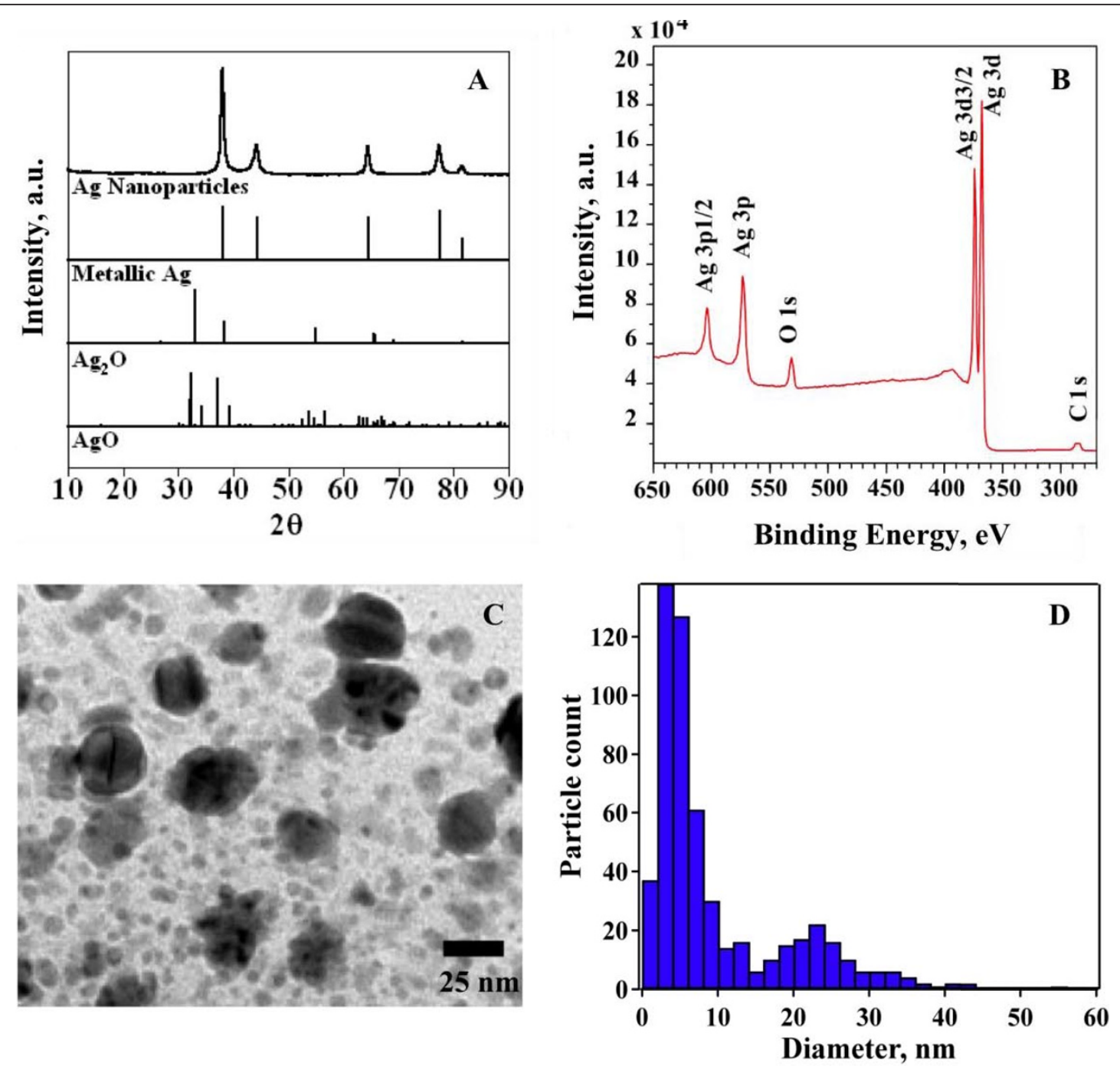

Figure 2 A. Powder X-ray diffraction patterns for nanosilver with patterns shown for three reference compounds including Ag, AgO and $\mathbf{A g O}_{2}$. B. X-ray photoelectron spectrum for nanosilver. C. TEM image of nanosilver and D. particle primary diameter count distribution from TEM images.

Gamble's buffers with the dissolved metal percentages of $0.03 \pm 0.002 \%$ and $0.07 \pm 0.003 \%$, correspondingly. This is in contrast to earlier studies on $\mathrm{Cu}$ nanoparticles that fully dissolved in ALF and showed 2\% dissolution in Gamble's solution [34].
SEM-EDS of the particles collected on TEM grids in the whole body chamber showed nanosilver aerosol between 50 and $100 \mathrm{~nm}$ detected at the characteristic X-ray energy for Ag (Figure 4). The size distributions of Ag nanoparticle aerosols measured during exposure

Table 1 Summary of physicochemical characterization data of Ag nanoparticles and Ag nanoparticle aerosols

\begin{tabular}{lll}
\hline Primary Particle Size & TEM & $5 \pm 2 \mathrm{~nm} ; 22 \pm 4 \mathrm{~nm}$ \\
\hline Crystalline or Amorphous Material, phase & XRD & Crystalline, face-centered cubic, metal \\
\hline Surface Functionality & XPS & $\mathrm{CO}_{3}{ }^{2-}, \mathrm{OH}^{-}, \mathrm{C}=\mathrm{O}, \mathrm{C}-\mathrm{O}-\mathrm{C}$ \\
\hline BET Surface Area & BET & $3 \pm 2 \mathrm{~m}^{2} / \mathrm{g}$ \\
\hline Aerosol Concentration & Gravimetric Analysis & $3.3 \pm 0.5 \mathrm{mg} / \mathrm{m}^{3}$ \\
\hline Aerosol Size Distribution** & SMPS & $79 \mathrm{~nm}(1.5)$ \\
\hline
\end{tabular}

* Bimodal distribution with smaller particles account for $85-90 \%$ of the total particle count.

**GM, nm, (GSD) in exposure chamber. 


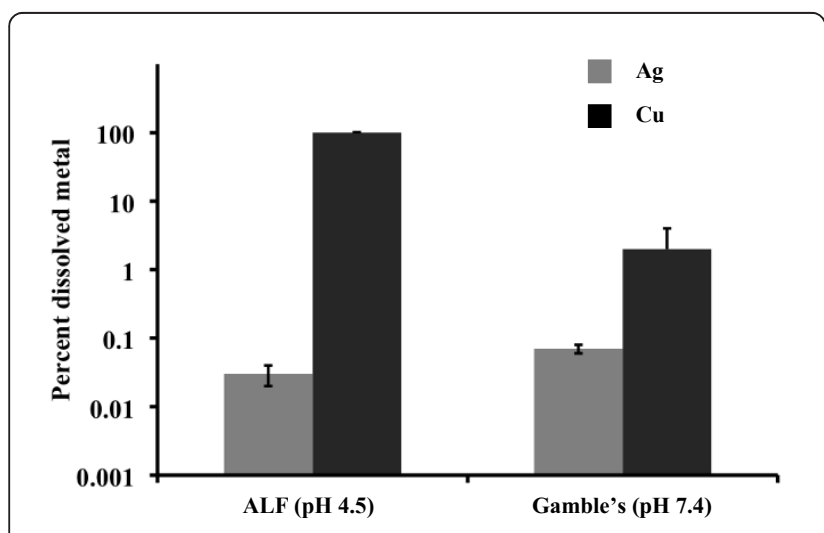

Figure 3 Dissolution results for $\mathrm{Ag}$ and $\mathrm{Cu}$ nanoparticles in ALF and Gamble's solution after 24 hours at $38^{\circ} \mathrm{C}$. Cu nanoparticle data are from Ref. 34

using an SMPS show that the nanosilver aerosols have a GM mobility diameter of $79 \mathrm{~nm}$ and GSD of 1.5 (Table 1 ). These measurements show that mice were exposed to agglomerates of nanosilver that were larger than the primary nanoparticles.

\section{Sub-acute Exposure}

The median amount of silver measured by ICP-OES in the lungs of nanosilver-exposed mice necropsied immediately after the exposure (0 wk group) was $31 \mu \mathrm{g} / \mathrm{g}$ lung (d.w.) (range 4.3 to $37.5 \mu \mathrm{g} / \mathrm{g}$ lung (d.w.)). This represents the loading in the lungs but not the nose, nasopharynx or trachea, which were not measured. The lungs of the $3 \mathrm{wk}$ mice had a median silver content of $10 \mu \mathrm{g} / \mathrm{g}$ lung (d.w.), and two of these five mice had no detectable silver. The mass concentration of silver in all sham-exposed mice was below the detection limit $(1.8 \mu \mathrm{g} / \mathrm{g}$ lung (d.w.)). Silver

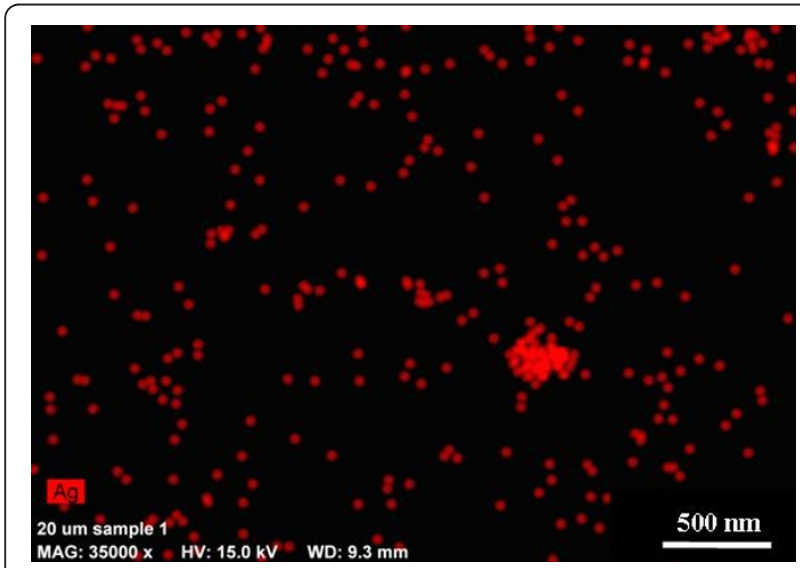

Figure 4 SEM-EDS mapping of nanosilver aerosols deposited on TEM grid during the exposure. The colored dots represent the elemental map for Ag at the expected characteristic X-ray energy for $\mathrm{Ag}$ and show, based on size, the presence of silver nanoparticle agglomerates. concentrations in the heart, liver, and brain were all below the detection limit. Assuming a minute volume of $25 \mathrm{ml} /$ $\mathrm{min}$, an aerosol concentration of $3.3 \mathrm{mg} / \mathrm{m}^{3}$ and a deposition coefficient of 0.15 in the tracheo-bronchiolar and pulmonary region, we estimate that $803 \mu \mathrm{g} \mathrm{Ag/g} \mathrm{lung} \mathrm{(d.w.)}$ was delivered to the lungs. Thus, $4 \%$ of the nominal Ag dose was found in the pulmonary region.

\section{Bronchoalveolar Lavage Fluid}

The total number of cells per mouse in BAL fluid was significantly increased in Ag-exposed mice necropsied at 0 wk $\left(92.3 \pm 3.7 \times 10^{3}\right)$ and 3 wks $\left(119.2 \pm 18.7 \times 10^{3}\right)$ post exposure, compared to sham-exposed mice (50.1 \pm $8.4 \times 10^{3}$ ). As shown in Figure 5A, the number of neutrophils per mouse in BAL fluid was significantly increased in mice necropsied at $0 \mathrm{wk}$ and 3 wks post exposure $(\mathrm{p}<$ 0.05 ). However, this change was of little biological significance. Additionally, there was no significant change in total cell numbers between mice necropsied at $0 \mathrm{wk}$ and 3 wks post exposure (Figure 5B). These results are in contrast to the effects of exposure to $12 \mathrm{~nm}$ copper nanoparticles with a copper oxide coating using the same protocol and with a similar airborne concentration $\left(3.68 \mathrm{mg} / \mathrm{m}^{3}\right)$ [34]. Data for copper shown for comparison in Figures $5 \mathrm{~A}$ and $5 \mathrm{~B}$ indicate a substantial recruitment of cells to the lungs and a substantial increase in total protein leaking from the epithelium. These resolved considerably after 3 wks without exposure.

We did not find significant differences between groups in total protein levels and activity of LDH in BAL fluid (Figure 5B). Concentrations of the following cytokines measured in BAL fluid were below the limit of detection: IL-6, TNF- $\alpha$, MCP-1, MIP-1 $\alpha$, GM-CSF (Table 2). We found slight, though statistically significant, elevation in IL-12(p40) and KC concentrations in the group necropsied at 0 wk post exposure compared with shamexposed mice $(\mathrm{p}<0.05)$. These concentrations were still increased, but not significantly in the mice necropsied 3 wks post exposure. In contrast, $\mathrm{Cu}$ nanoparticles induced substantial elevations in MCP-1, IL-12(p40), MIP- $1 \alpha, \mathrm{KC}$ and TNF $\alpha$. IL- 6 and GM-CSF were also significantly elevated (Table 2).

The mean concentrations of Ag ion in BAL supernatants were $13.9 \pm 0.9 \mu \mathrm{g} / \mathrm{L}$ and $1.7 \pm 0.2 \mu \mathrm{g} / \mathrm{L}$ in animals necropsied at $0 \mathrm{wk}$ and 3 wks post exposure, respectively. Silver was not detectable in BAL fluid from control mice.

No pathologic changes were found in Ag-exposed animals or sham-exposed mice. No signs of inflammatory cell infiltrate, alveolitis, perivasculitis, lymphoid agglomerates, epithelial damage, granulomas, giant cells or fibrosis were observed. Particle-laden macrophages were found in the BAL fluid of nanosilver-exposed mice as well as in the lung parenchyma immediately after the last exposure as shown using dark field microscopy (Figures 6A) and also 

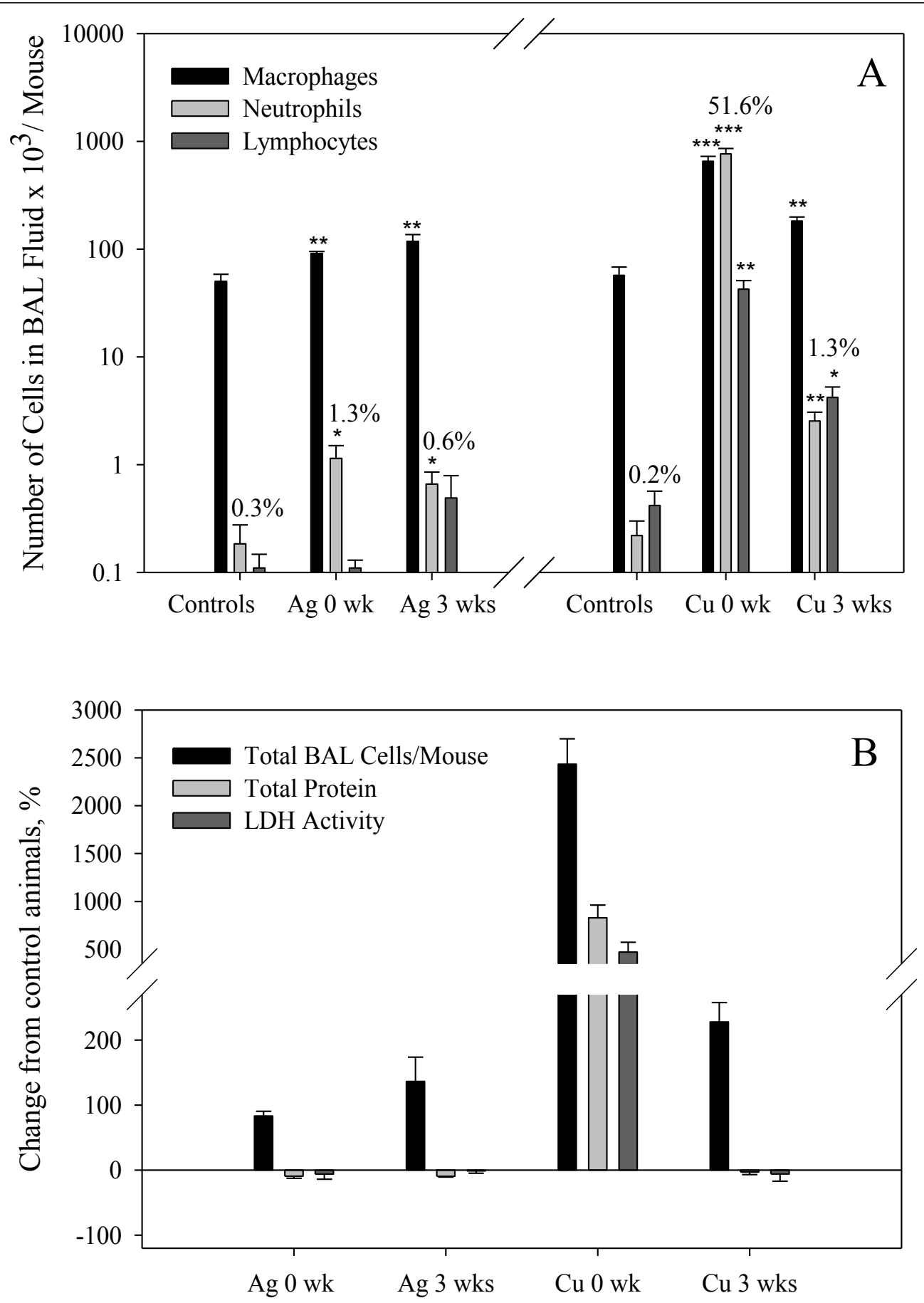

\section{Exposure Group}

Figure 5 Results from analysis of BAL fluid after sub-acute exposure to Ag nanoparticles ( $\mathbf{n}=\mathbf{5}$ per each group). Data from Ref. 34 for Cu nanoparticle exposure ( $n=6$ per control group, $n=8$ per Cu-exposed group) using the same protocol are shown for comparison. Number and percentages of differential cells in $\mathrm{BAL}^{*} \mathrm{p}<0.05$ and ${ }^{* *} p<0.01$ (A). Percent change from control animals in total cells, total protein and activity of LDH (B). Data are expressed as mean \pm SE. 
Table 2 Cytokine concentrations in BAL fluid from mice exposed to Ag nanoparticles by inhalation. Data from Ref. 34 for $\mathrm{Cu}$ nanoparticle exposure using the same protocol are shown for comparison

\begin{tabular}{|c|c|c|c|c|c|c|c|}
\hline Exposure & IL-6 & IL-12(p40) & TNF- $\alpha$ & KC & MCP-1 & MIP-1 $\alpha$ & GM-CSF \\
\hline \multicolumn{8}{|l|}{ Group } \\
\hline Silver & $\mathrm{pg} / \mathrm{ml}$ & & & & & & \\
\hline Controls & ND & $29.1 \pm 2.9$ & ND & ND & ND & ND & ND \\
\hline Ag 0 wk post exposure & $\mathrm{ND}$ & $64.1 \pm 10.6^{*}$ & $\mathrm{ND}$ & $4.24 \pm 0.88^{*}$ & ND & ND & ND \\
\hline $\mathrm{Ag} 3$ wks post exposure & ND & $53.6 \pm 21.9$ & ND & $2.96 \pm 0.54$ & ND & ND & ND \\
\hline Detection limit & 0.67 & 0.73 & 44.3 & 1.77 & 9.58 & 27.31 & 1.48 \\
\hline Copper & & & & $\mathrm{pg} / \mathrm{ml}$ & & & \\
\hline Controls & $\mathrm{ND}$ & $35.0 \pm 6.8$ & $21.4 \pm 3.3$ & $0.90 \pm 0.12$ & ND & ND & $0.16 \pm 0.08$ \\
\hline Cu 0 wk post-exposure & $82.8 \pm 13.8^{*}$ & $1210 \pm 10.1^{*}$ & $161 \pm 10.4^{*}$ & $215 \pm 17.0^{*}$ & $4400 \pm 401^{*}$ & $309 \pm 37.2^{*}$ & $70.2 \pm 10.9^{*}$ \\
\hline Cu 3 wk post-exposure & $\mathrm{ND}$ & $42.7 \pm 4.8$ & $17.3 \pm 1.6$ & $1.44 \pm 0.12$ & ND & ND & $0.27 \pm 0.13$ \\
\hline Detection limit & 0.11 & 0.08 & 13 & 0.19 & 3.44 & 2.01 & 0.08 \\
\hline
\end{tabular}

ND Not detectable.

* Significantly different from sham-exposed animals $(p<0.05)$.

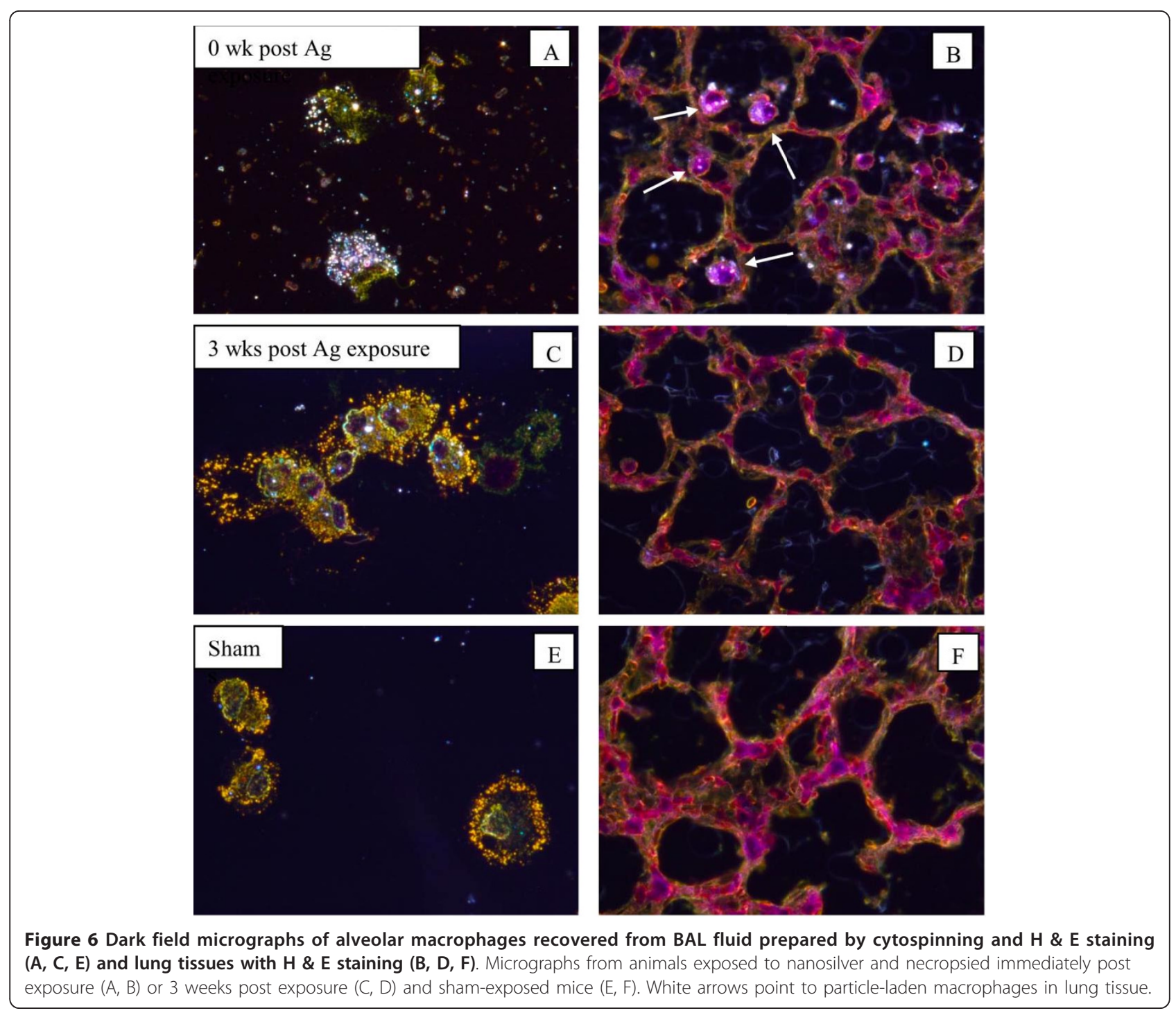


by TEM-EDS of BAL macrophages (Figure 7A, B). Three weeks post exposure there was still evidence of silver particles in macrophage phagosomes (Figures 6C). However, there was a higher percentage of macrophages (76\%) found in BAL fluid of mice necropsied at 0 wk post exposure as compared to mice necropsied 3 wks post exposure (28\%).

\section{Discussion}

The purpose of this study was to assess the biological response of mice to inhaled nanosilver and to determine the amount of silver retained in lungs and other organs. We observed nanosilver agglomerates in the inhalation chamber with a GM mobility diameter of $79 \mathrm{~nm}$ (Table 1) and SEM-EDS analysis showed the presence of Ag aerosols in the exposure chamber (Figure 4). ICP-OES analysis of nanosilver incubated in the simulated biological fluids revealed negligible formation of Ag ions (Figure 3). Moreover, most of the nanoparticles, even PVP coated particles, aggregated and settled out in these simulated biological fluids at the relatively high concentrations investigated after 24 hours and the XRD analysis of the precipitates revealed the presence of metallic Ag similar to Figure 2A.

Since there are limited data available on the concentrations of nanosilver in consumer products or in the air in occupational settings where materials with nanosilver are being produced, we established exposure concentrations in the whole-body chamber that were similar to our previous studies of toxicity assessment of titanium dioxide, copper, and iron. This facilitated comparison of toxicologic responses with our previous studies with different nanomaterials $[34,41,42]$. The median amount of silver measured in lungs of nanosilver-exposed mice was 31 and $10 \mu \mathrm{g} / \mathrm{g}$ lung (d.w.) for $0 \mathrm{wk}$ and $3 \mathrm{wks}$ animals, respectively, which corresponds to $100 \mu \mathrm{g} / \mathrm{L}$ and $32 \mu \mathrm{g} /$ L Ag concentrations measured by ICP-OES in the lungs. Moreover, low Ag concentrations in the particle-free supernatants of BAL fluid $(13.9 \pm 0.9 \mu \mathrm{g} / \mathrm{L}$ and $1.7 \pm 0.2$ $\mu \mathrm{g} / \mathrm{L}$ in animals necropsied at $0 \mathrm{wk}$ and 3 wks post exposure, respectively) were detected by ICP-MS. Higher concentration of Ag measured in BAL fluid from animals necropsied at 0 wk agrees with the higher amount of Ag measured in the 0 wk lungs. Thus, these data suggest that there is some evidence for Ag dissolution in the lungs. It has been shown that Ag nanoparticles might fractionate (or dissolve) in aquatic environments at very low $(<100 \mu \mathrm{g} / \mathrm{L})$ concentrations since nanoparticles might be less aggregated than in higher concentrated samples $[43,44]$.

The amount of Ag detected in the 0 wk group corresponds to the lung burden accumulated by a $70 \mathrm{~kg}$ person exposed to a very high concentration of $1.0 \mathrm{mg} / \mathrm{m}^{3}$ for 16.6 hours. Hence, this represents a substantial dose. To calculate the exposure time of the human, we assumed exposure concentration of $1.0 \mathrm{mg} / \mathrm{m}^{3}$, frequency of breathing 15 breaths/min, tidal volume of the lungs $600 \mathrm{~mL} /$ breath, pulmonary deposition fraction for $80 \mathrm{~nm}$ particles of 0.4 (based on human model by Cassee et al. [38]) and delivered Ag dose to human 3574 $\mu \mathrm{g}$. The amount of nanosilver measured from the pulmonary region of the exposed mice was below the estimated levels based on the minute ventilation, deposition fraction and gravimetric measurements of chamber outflow. This could be due to lower breathing zone concentrations for the mice than expected from the chamber
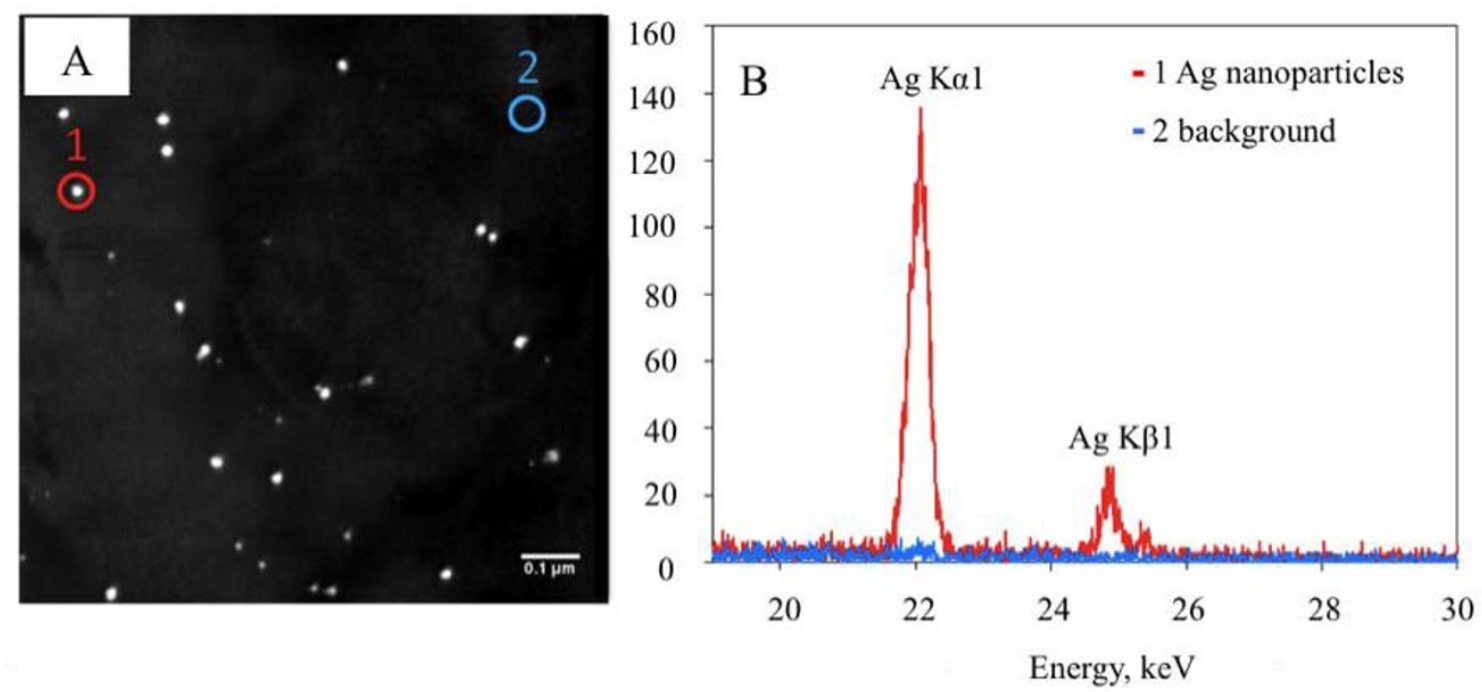

Figure 7 Particles found inside alveolar macrophages were identified using TEM-EDS as silver (A, B). 
outflow measurements, an overestimation of the deposition coefficient for the pulmonary region, clearance by mucociliary escalator to the trachea or gastrointestinal tract, translocation of nanosilver to other organs that we did not measure, or poor sensitivity of the ICP-OES assay methods. Work by Asgharian and colleagues has shown that particles below $10 \mathrm{~nm}$ are deposited in the nasopharynx and tracheal regions with little penetration into the pulmonary region [37]. Deposition occurs primarily through axial transport by diffusion and convective mixing. Model predictions show that for nanoparticles in the $80 \mathrm{~nm}$ range, the deposition fraction for the pulmonary region is about 0.4 in humans (for mouth breathing) and 0.15 in rodents which are obligate nose breathers [38].

We observed increased total cell numbers in Agexposed animals (mainly macrophages) and a slight inflammatory response (increased number of neutrophils in BAL fluid) in 0 wk mice (Figures 5). Recruitment of macrophages is a normal clearance mechanism following particle exposure $[45,46]$. Neutrophilia decreased after 3 weeks without exposure, however total number of cells remained elevated. Interestingly, comparison of these results to other metal nanoparticle exposures studied by our group shows that nanosilver is most similar to iron nanoparticles, which are coated with an iron oxide layer. In the previous study, iron nanoparticles were found to be significantly less toxic than copper nanoparticles [34]. Copper nanoparticles induced a 25 times increase in the number of BAL cells after sub-acute exposure as well as an increase in most cytokines.

The levels of total protein and LDH activity in BAL fluid did not change significantly with exposure to nanosilver (Figure 5B). This is another indication of low nanosilver toxicity at the exposure concentration used in this study. Of 7 cytokines tested only two, IL12 (p40) and $\mathrm{KC}$, had slightly elevated concentrations at 0 wk and most were below detection even using a very sensitive assay (Table 2). IL-12(p40), which exhibited the most elevated concentration, functions primarily to induce naïve $\mathrm{T}$-cells to differentiate to $\mathrm{Th}_{0}$ cells and to enhance NK cell activity. It is produced by dendritic cells and macrophages [47]. This is consistent with the observed doubling in BAL macrophages but is very low in comparison to our previous study of $\mathrm{Cu}$ nanoparticles when we detected a mean level of IL-12 (p40) of $1210 \mathrm{pg} / \mathrm{ml}$ (Table 2). Keratinocyte-derived cytokine $(\mathrm{KC})$ that is involved in chemotaxis and cell activiation of neutrophils, was also slightly elevated. However, this increase was 50 times lower than in $\mathrm{Cu}$ exposed mice. Furthermore, other chemokines/cytokines such as MCP-1, MIP-1 $\alpha$, TNF- $\alpha$, RANTES, GMCSF were much more elevated in case of $\mathrm{Cu}$ nanoparticle exposure [34].
We observed agglomerated nanosilver in macrophages that were recovered from BAL fluid and also in lung tissue (Figure 6). Dark-field microscopy revealed lower particle load at $3 \mathrm{wks}$ post exposure than immediately post exposure, showing some particle clearance or possible translocation from the airways to the interstitium. Lung tissues were without remarkable pathological changes. In a 90 day rat study, lung inflammation and an increase in granulomatous lesions as well as alterations in lung functions were observed [48]. In another inhalation study in rats, minimal, toxicologically insignificant effects of nanosilver on the nasal respiratory mucosa were indicated [49].

Here we used the same experimental mouse model and exposure system as in our previous studies on the toxicity of different nanomaterials $[34,41,42]$. Of all nanomaterials studied in the size range from ca. 5 to $20 \mathrm{~nm}\left(\mathrm{TiO}_{2}, \mathrm{Fe}\right.$, $\mathrm{Cu}, \mathrm{Ag})$, copper nanoparticles, which had a copper oxide coating, induced much higher total cell and neutrophil recruitment in BAL fluid, elevated total protein, activity of LDH and levels of inflammatory cytokines in BAL fluid than nanosilver [50]. This increased inflammatory response in copper-exposed mice was associated with the nanoparticle size and increased ion concentration produced from the dissolving nanoparticles in vivo. Mice exposed sub-acutely to $2-5 \mathrm{~nm} \mathrm{TiO}_{2}$ nanoparticles showed a moderate inflammatory response at 0,1 , and 2 weeks post-exposure that resolved after 3 weeks post-exposure. Iron nanoparticles induced a minimal inflammatory response similar to nanosilver. The toxicity of Ag nanoparticles in this murine inhalation model was similar to Fe nanoparticles. Both types do not dissolve in artificial interstitial fluid which could be associated with the negligible toxic response observed for metal and metal oxide nanomaterials. Other studies also support a role for solubility of nanomaterials in their toxicity $[51,52]$.

\section{Conclusions}

The toxicity of nanosilver is a highly debated topic in the literature and in reports of the U.S. Environmental Protection Agency. Our study indicates that $40 \mathrm{hr}$ inhalation of $3.3 \mathrm{mg} / \mathrm{m}^{3}$ nanosilver induced minimal pulmonary toxicity or inflammation. Methods used to evaluate toxic responses in this study indicate much lower inflammatory response of mice to silver nanoparticles than to copper nanoparticles. These observations are in agreement with other studies, which indicate that much higher exposure doses of silver nanoparticles than other metals are needed to induce significant inflammation.

\section{Acknowledgements}

This work was supported by NIOSH Grant R01OH009448 and NIEHS Grant P30 ES05605. We thank Drs. Jonas Baltrusaitis and Sherrie Elzey for help with XPS and TEM analyses. 


\section{Author details}

'Department of Chemistry, University of lowa, lowa City, IA 52242, USA. ${ }^{2}$ Department of Occupational and Environmental Health, University of lowa lowa City, IA 52242, USA. ${ }^{3}$ Interdisciplinary Graduate Program in Human Toxicology, University of lowa, lowa City, IA 52242, USA.

\section{Authors' contributions}

LVS participated in the nanoparticle characterization, conducted dissolution study and analysis of elements in mice organs, drafted parts of the manuscript and integrated the text into a complete draft; AAD drafted parts of the manuscript related to the toxicity results, conducted the mouse exposure studies, BAL evaluation and histopathological analyses; JSK conducted the mouse exposures, BAL evaluation, histopathology results analysis and ICP-OES organ preparation and analyses; HP participated in the nanoparticle characterization and in ICP-OES analysis of mice organs; PTO led the design of the exposure and generation system, and coordinated the exposure assessment and aerosol characterization; VHG designed the integrated study, participated in its coordination and completion including analysis of nanoparticle characterization data, manuscript outlining and writing, and editing of final manuscript; PST designed and coordinated all aspects of the toxicity study including experimental design and analysis and authored the final manuscript. All authors read and approved the final manuscript.

\section{Competing interests}

Vicki H. Grassian is a consultant and a member of the scientific advisory board of Vive Nano (Toronto, Canada) and has stock shares in Nanoscale Corp (Manhattan, Kansas).

Received: 29 September 2010 Accepted: 25 January 2011 Published: 25 January 2011

\section{References}

1. Peters TM, Elzey S, Johnson R, Park H, Grassian VH, Maher T, O'Shaughnessy P: Airborne Monitoring to Distinguish Engineered Nanomaterials from Incidental Particles for Environmental Health and Safety. Journal of Occupational and Environmental Hygiene 2009, 6:73-81.

2. Adachi K, Buseck PR: Hosted and free-floating metal-bearingatmospheric nanoparticles in Mexico city. Environmental Science \& Technology 2010, asap article.

3. Buseck PR, Adachi K: Nanoparticles in the Atmosphere. Elements 2008, 4:389-394

4. Baun A, Hartmann NB, Grieger KD, Hansen SF: Setting the limits for engineered nanoparticles in European surface waters - are current approaches appropriate? Journal of Environmental Monitoring 2009, 11:1774-1781.

5. Kaegi R, Ulrich A, Sinnet B, Vonbank R, Wichser A, Zuleeg S, Simmler H, Brunner S, Vonmont H, Burkhardt M, Boller M: Synthetic TiO2 nanoparticle emission from exterior facades into the aquatic environment. Environmental Pollution 2008, 156:233-239.

6. Wijnhoven SWP, Peijnenburg WJGM, Herberts CA, Hagens WI, Oomen AG, Heugens EHW, Roszek B, Bisschops J, Gosens I, Van De Meent D, et al: Nano-silver - a review of available data and knowledge gaps in human and environmental risk assessment. Nanotoxicology 2009, 3:109-138.

7. Kim YS, Kim JS, Cho HS, Rha DS, Kim JM, Park JD, Choi BS, Lim R, Chang HK, Chung YH, et al: Twenty-eight-day oral toxicity, genotoxicity, and genderrelated tissue distribution of silver nanoparticles in Sprague-Dawley rats. Inhalation Toxicology 2008, 20:575-583.

8. Kim JS, Kuk E, Yu KN, Kim JH, Park SJ, Lee HJ, Kim SH, Park YK, Park YH, Hwang $C Y$, et al: Antimicrobial effects of silver nanoparticles. Nanomedicine-Nanotechnology Biology and Medicine 2007, 3:95-101.

9. Chen X, Schluesener HJ: Nanosilver: A nanoproduct in medical application. Toxicology Letters 2008, 176:1-12.

10. Hussain SM, Hess KL, Gearhart JM, Geiss KT, Schlager JJ: In vitro toxicity of nanoparticles in BRL 3A rat liver cells. Toxicology in Vitro 2005, 19:975-983.

11. Hussain SM, Javorina AK, Schrand AM, Duhart HM, Ali SF, Schlager JJ: The Interaction of Manganese Nanoparticles with PC-12 Cells Induces Dopamine Depletion. Toxicol Sci 2006, 92:456-463.

12. Kvitek L, Vanickova M, Panacek A, Soukupova J, Dittrich M, Valentova E, Prucek R, Bancirova M, Milde D, Zboril R: Initial Study on the Toxicity of Silver Nanoparticles (NPs) against Paramecium caudatum. Journal of Physical Chemistry C 2009, 113:4296-4300.
13. Liu RT, Sun F, Zhang LJ, Zong WS, Zhao XC, Wang L, Wu RL, Hao XP: Evaluation on the toxicity of nanoAg to bovine serum albumin. Science of the Total Environment 2009, 407:4184-4188.

14. Navarro E, Piccapietra F, Wagner B, Marconi F, Kaegi R, Odzak N, Sigg L, Behra R: Toxicity of Silver Nanoparticles to Chlamydomonas reinhardtii. Environmental Science \& Technology 2008, 42:8959-8964.

15. Lanone S, Rogerieux F, Geys J, Dupont A, Maillot-Marechal E, Boczkowski J Lacroix G, Hoet P: Comparative toxicity of 24 manufactured nanoparticles in human alveolar epithelial and macrophage cell lines. Particle and Fibre Toxicology 2009, 6:14.

16. Bar-llan O, Albrecht RM, Fako VE, Furgeson DY: Toxicity Assessments of Multisized Gold and Silver Nanoparticles in Zebrafish Embryos. Small 2009, 5:1897-1910.

17. Soto K, Garza KM, Murr LE: Cytotoxic effects of aggregated nanomaterials. Acta Biomaterialia 2007, 3:351-358.

18. Soto KF, Carrasco A, Powell TG, Garza KM, Murr LE: Comparative in vitro cytotoxicity assessment of some manufactured nanoparticulate materials characterized by transmission electron microscopy. Journal of Nanoparticle Research 2005, 7:145-169.

19. AshaRani PV, Mun GLK, Hande MP, Valiyaveettil S: Cytotoxicity and Genotoxicity of Silver Nanoparticles in Human Cells. Acs Nano 2009, 3:279-290.

20. Sayes CM, Reed KL, Warheit DB: Assessing toxicity of fine and nanoparticles: Comparing in vitro measurements to in vivo pulmonary toxicity profiles. Toxicol Sci 2007, 97:163-180.

21. Seagrave J, McDonald JD, Mauderly JL: In vitro versus in vivo exposure to combustion emissions. Experimental and Toxicologic Pathology 2005, 57:233-238.

22. Brandenberger $C$, Rothen-Rutishauser B, Muhlfeld C, Schmid O, Ferron GA, Maier KL, Gehr P, Lenz AG: Effects and uptake of gold nanoparticles deposited at the air-liquid interface of a human epithelial airway model. Toxicology and Applied Pharmacology 2010, 242:56-65.

23. Grigg J, Tellabati A, Rhead S, Almeida GM, Higgins JA, Bowman KJ, Jones GD, Howes PB: DNA damage of macrophages at an air-tissue interface induced by metal nanoparticles. Nanotoxicology 2009, 3:348-354.

24. Lenz AG, Karg E, Lentner B, Dittrich V, Brandenberger C, RothenRutishauser B, Schulz H, Ferron GA, Schmid O: A dose-controlled system for air-liquid interface cell exposure and application to zinc oxide nanoparticles. Particle and Fibre Toxicology 2009, 6:32.

25. Thorne PS, Adamcakova-Dodd A, Kelly KM, O'Neill ME, Duchaine C: Metalworking fluid with mycobacteria and endotoxin induces hypersensitivity pneumonitis in mice. American Journal of Respiratory and Critical Care Medicine 2006, 173:759-768.

26. Driscoll KE, Costa DL, Hatch G, Henderson R, Oberdorster G, Salem H, Schlesinger RB: Intratracheal instillation as an exposure technique for the evaluation of respiratory tract toxicity: Uses and limitations. Toxicol Sci 2000, 55:24-35.

27. Osier M, Oberdorster G: Intratracheal inhalation vs intratracheal instillation: Differences in particle effects. Fundamental and Applied Toxicology 1997, 40:220-227.

28. Quadros ME, Marr LC: Environmental and Human Health Risks of Aerosolized Silver Nanoparticles. Journal of the Air \& Waste Management Association 2010, 60:770-781.

29. Ji JH, Jung JH, Kim SS, Yoon JU, Park JD, Choi BS, Chung YH, Kwon $\mathbb{H}_{\text {, }}$ Jeong J, Han BS, et al: Twenty-eight-day inhalation toxicity study of silver nanoparticles in Sprague-Dawley rats. Inhalation Toxicology 2007, 19:857-871.

30. Takenaka S, Karg E, Moller W, Roth C, Ziesenis A: A morphologic study on the fate of ultrafine silver particles: Distribution pattern of phagocytized metallic silver in vitro and in vivo. Inhalation Toxicology 2000, 12:291-299.

31. Takenaka S, Karg E, Roth C, Schulz H, Ziesenis A, Heinzmann U, Schramel P, Heyder J: Pulmonary and systemic distribution of inhaled ultrafine silver particles in rats. Environmental Health Perspectives 2001, 109:547-551.

32. Sung JH, Ji JH, Yoon JU, Kim DS, Song MY, Jeong J, Han BS, Han JH, Chung YH, Kim J, et al: Lung function changes in Sprague-Dawley rats after prolonged inhalation exposure to silver nanoparticles. Inhalation Toxicology 2008, 20:567-574.

33. Elzey S, Grassian VH: Agglomeration, isolation and dissolution of commercially manufactured silver nanoparticles in aqueous environments. Journal of Nanoparticle Research 2010, 12:14. 
34. Pettibone JM, Adamcakova-Dodd A, Thorne PS, O'Shaughnessy PT, Weydert JA, Grassian VH: Inflammatory response of mice following inhalation exposure to iron and copper nanoparticles. Nanotoxicology 2008, 2:189-204.

35. Stopford W, Turner J, Cappellini D, Brock T: Bioaccessibility testing of cobalt compounds. Journal of Environmental Monitoring 2003, 5:675-680.

36. O'Shaughnessy PT, Achutan C, O'Neill ME, Thorne PS: A small whole-body exposure chamber for laboratory use. Inhalation Toxicology 2003, 15:251-263.

37. Asgharian B, Price OT: Airflow distribution in the human lung and its influence on particle deposition. Inhalation Toxicology 2006, 18:795-801.

38. Cassee FR, Freijer Jl, Subramaniam R, Asgharian B, Miller FJ, van Bree L, Rombout PJA: Development of a model for human and rat airway particle deposition: implications for risk assessment. Bilthoven, the Netherlands: Dutch National Institute of Public Health and Environment (RIVM); 1999.

39. Mueller-Anneling $L$, O'Neill ME, Thorne PS: Biomonitoring for assessment of organic dust-induced lung inflammation. European Respiratory Journal 2006, 27:1096-1101.

40. Kvitek L, Panacek A, Soukupova J, Kolar M, Vecerova R, Prucek R, Holecova M, Zboril R: Effect of surfactants and polymers on stability and antibacterial activity of silver nanoparticles (NPs). Journal of Physical Chemistry C 2008, 112:5825-5834.

41. Grassian VH, O'Shaughnessy PT, Adamcakova-Dodd A, Pettibone JM, Thorne PS: Inhalation exposure study of titanium dioxide nanoparticles with a primary particle size of 2 to $5 \mathrm{~nm}$. Environmental Health Perspectives 2007, 115:397-402.

42. Grassian VH, Adamcakova-Dodd A, Pettibone JM, O'Shaughnessy PT, Thorne PS: Inflammatory response of mice to manufactured titanium dioxide nanoparticles: Comparison of size effects through different exposure routes. Nanotoxicology 2007, 1:211-226.

43. Kennedy AJ, Hull MS, Bednar AJ, Goss JD, Gunter JC, Bouldin JL, Vikesland PJ, Steevens JA: Fractionating Nanosilver: Importance for Determining Toxicity to Aquatic Test Organisms. Environ Sci Technol 2010, 44:9571-9577.

44. Liu J, Hurt RH: Ion Release Kinetics and Particle Persistence in Aqueous Nano-Silver Colloids. Environ Sci Technol 2010, 44:2169-2175.

45. Kreyling WG, Scheuchm G: Clearance of particles deposited in the lungs. In Particle-Lung Interactions. Edited by: Gehr P HJ. New York: Marcel Dekker; 2000:323-376.

46. Geiser M, Casaulta M, Kupferschmid B, Schulz H, Semirriler-Behinke M, Kreyling $W$ : The role of macrophages in the clearance of inhaled ultrafine titanium dioxide particles. American Journal of Respiratory Cell and Molecular Biology 2008, 38:371-376.

47. Trinchieri G, Pflanz S, Kastelein RA: The IL-12 family of heterodimeric cytokines: New players in the regulation of T cell responses. Immunity 2003, 19:641-644.

48. Sung JH, Ji JH, Park JD, Yoon JU, Kim DS, Jeon KS, Song MY, Jeong J, Han BS, Han JH, et al: Subchronic Inhalation Toxicity of Silver Nanoparticles. Toxicol Sci 2009, 108:452-461.

49. Hyun JS, Lee BS, Ryu HY, Sung JH, Chung KH, Yu IJ: Effects of repeated silver nanoparticles exposure on the histological structure and mucins of nasal respiratory mucosa in rats. Toxicology Letters 2008, 182:24-28.

50. Adamcakova-Dodd A, Thorne PS, Grassian VH: In Vivo Toxicity Studies of Metal and Metal Oxide Nanoparticles. In Handbook of Systems Toxicology. Edited by: Daniel A Cascinao, Saura C Sahu. Chichester, UK: John Wiley 2011:803-834.

51. Brunner TJ, Wick P, Manser P, Spohn P, Grass RN, Limbach LK, Bruinink A, Stark WJ: In vitro cytotoxicity of oxide nanoparticles: Comparison to asbestos, silica, and the effect of particle solubility. Environmental Science \& Technology 2006, 40:4374-4381.

52. Xia T, Kovochich M, Liong M, Madler L, Gilbert B, Shi HB, Yeh Jl, Zink Jl, Nel AE: Comparison of the Mechanism of Toxicity of Zinc Oxide and Cerium Oxide Nanoparticles Based on Dissolution and Oxidative Stress Properties. Acs Nano 2008, 2:2121-2134

doi:10.1186/1743-8977-8-5

Cite this article as: Stebounova et al:: Nanosilver induces minimal lung toxicity or inflammation in a subacute murine inhalation model. Particle and Fibre Toxicology 2011 8:5.

\section{Submit your next manuscript to BioMed Central and take full advantage of:}

- Convenient online submission

- Thorough peer review

- No space constraints or color figure charges

- Immediate publication on acceptance

- Inclusion in PubMed, CAS, Scopus and Google Scholar

- Research which is freely available for redistribution 